\title{
The Sickle Cell Pain Action Plan: A low-literacy, pictographic tool to enhance self-management and guideline concordance
}

Patrick Reeves $^{1}$, Philip Rogers ${ }^{2}$, Sean Hipp ${ }^{3}$, Richard Zanetti ${ }^{2}$, Sofia Echelmeyer ${ }^{4}$, Donald Rees $^{2}$, and Dina Parekh ${ }^{2}$

${ }^{1}$ Uniformed Services University of the Health Sciences F Edward Hébert School of Medicine ${ }^{2}$ Walter Reed National Military Medical Center

${ }^{3}$ Brooke Army Medical Center

${ }^{4}$ Uniformed Services University of the Health Sciences

March 1, 2022

\section{Hosted file}

Sickle Cell_Letter to Editor_PTR_28FEB.docx available at https://authorea.com/users/463037/ articles/558254-the-sickle-cell-pain-action-plan-a-low-literacy-pictographic-tool-toenhance-self-management-and-guideline-concordance

\section{Hosted file}

Table 1_Sickle Cell Pain.docx available at https://authorea.com/users/463037/articles/558254the-sickle-cell-pain-action-plan-a-low-literacy-pictographic-tool-to-enhance-selfmanagement-and-guideline-concordance

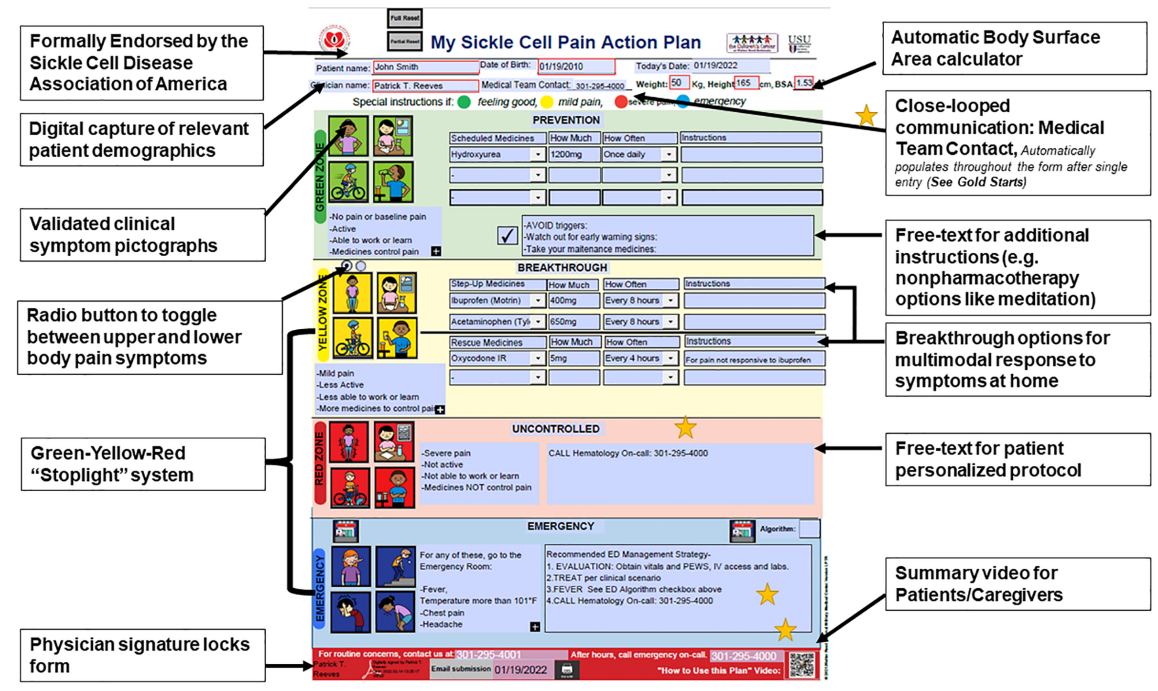

